\title{
An Empirical Study of Environmental Attitude among Higher Primary School Teachers of India and Iran
}

\author{
Maryam Larijani* and K. Yeshodhara** \\ Department of Education, University of Mysore, Mysore 570 006, Karnataka, India \\ Email: <m.edu@rediffmail.com>*,yesha_k@yahoo.co.in**
}

KEYWORDS Environmental Attitude. Health And Hygiene. Wildlife. Forests. Polluters. Population Explosion and Environmental Concern

\begin{abstract}
The present study is an attempt to study the environmental attitude of Indian and Iranian higher primary school teachers in various components. The article tries to answer whether Indian and Iranian teachers differ in their attitude towards environment. A total of 1000 teachers (500 Indian and 500 Iranian) teaching in $6^{\text {th }}$ and $7^{\text {th }}$ standards were randomly selected for the present study. The environmental attitude scale was employed to assess the level of attitude in each component. It consisted of components on Health and Hygiene, Wildlife, Forests, Polluters, Population explosion and Environmental concern. The data on Indian sample was collected in Mysore city and data on Iranian teachers was collected in Hamedan city. MANOVA was employed to find out the significance of difference between the teachers of two countries as well as male and female teachers. Results revealed that Iranian teachers had most favourable attitude in all the components except in Wildlife. Only in Wildlife Indian teachers had most favourable attitude as compared to their Iranian counterparts. Male and female teachers differed significantly in most of the factors except population explosion, and total attitude scores. Implications environmental education also stressed.
\end{abstract}

\section{INTRODUCTION}

It is observed that degradation of environment mostly occurs due to destruction of natural environs. Now there is a cry all over for protection and preservation of such natural resources. This can only be possible if we have a right type of attitude towards such issues and if we have proper awareness in the related matters. It is widely accepted that the development of such awareness and attitude can be possible through environmental education. Education is an important social instrument and means, which act as a catalyst in improvement of different aspects of life. Knowledge, awareness, skills, values and attitudes acquired through education help one to lead a desired quality of life. In order to protect and conserve the environment enabling people to lead quality life, emphasis has been given to environmental education in both formal and non-formal system of education. In formal system of education, teaching of environmental education depends not only on curriculum and other facilities provided to the students, but also the quality of teachers in terms of knowledge, awareness, attitude and skills relating to environmental education. Teacher plays a very significant role in developing desirable attitude towards awareness about environment among students.
Today the global concern is to struggle again environment pollution and maintain the standard of human environment. Environment in developing countries like India and Iran have been threatened by problems like poverty, pollution and over population (India) and degradation and depletion of environment (Iran). In addition to the industrial revolution, unprecedented scientific and technological revolution has resulted in disastrous changes in the environment leading to environmental degradation / crisis. The speed and nature of environmental change (particularly man-induced change) in recent years have brought about a series of environmental problems of global magnitude - including population explosion, energy resources and utilization, the provision of food supplies, exploitation of raw materials and environmental problem (Yashodhara, 2003). This environmental degradation or crisis has become a serious issue as it threatens not only the tranquility of people's existence, but their health and lives as well. As such, the environmental protection and preservation has been an urgent need of the hour. Realizing its importance, the Indian States has also enshrined it into Constitution which requires both the state and citizen to "Protect, preserve and improve the environment".

Although Iran established Department of Environment in 1971, long-term environmental 
concerns often have been subjugated to shorterterm industrial production and political goals. Iranian environmental protection efforts in the $1970 \mathrm{~s}$ focused on conservation, with the establishment of a number of national parks, national monuments, and wildlife refuges throughout the country. Iran maintained this focus after the Islamic Revolution, enshrining environmental protection in the Constitution. Article 50 of the Constitution reads: "In the Islamic Republic of Iran protection of the environment, in which present and future generations should enjoy a transcendent social life, is regarded as a public duty.

A survey of literature on environmental attitude yielded very less promising results. Study by Mercy and Arjunan (2005), on school children revealed that boys had better attitude than girls, as well as urban children had better attitude than rural children etc. Jinarajan (1999) in a study on environmental attitude towards environmental education of student teachers found that gender, media of instruction; socioeconomic status had impact on environmental attitude. Contradictorily, Shaila (2003) in her study on secondary school teachers found no difference among gender, types of school management, arts and science teachers, domicile on environmental attitude. Most of the studies done earlier focused on environmental awareness. Cross-cultural studies have been not at all traced on environmental attitude among teachers. Also, minimum efforts have been directed at finding out the level of attitude on environmental issues and environmental education among the school teachers and learners of the program. The present study is taken up to assess the level of environmental attitude among Indian and Iranian higher primary school teachers. It is hypothesized that Iranian teachers will have favourable attitude towards various issues compared to Indian teachers.

\section{METHOD OF STUDY}

Participants: A total of 1000 teachers selected from India and Iran. The details of selection are as follows. In India teachers from Mysore and in Iran teachers from Hamedan city were randomly selected.

This sample of study consists of two stage sampling

- Selection of schools

- Selection of teachers.
1. Selection of Schools: Schools were selected randomly 50 from Mysore city in India and 50 from Hamedan city in Iran. Therefore a total of 100 schools were selected for the study.

2. Selection of Teachers: All the teachers of all the subjects (Science, Social Studies, Mathematics and Languages) teaching sixth and seventh standard in each school were considered as sample for the study. Thus the sample of study consisted of 1000 teachers of higher primary schools (500 from Mysore 250 male +250 female (India) and 500 from Hamedan 252 male +248 female (Iran).

\section{Research Tool}

The Taj Environmental Attitude Scale (TEAS) was developed by Dr. Haseen Taj in 2001. Following the Likert's method of summated rating procedure, TEAS was developed with 61 items consisting six areas. The six areas dealt with the scale are attitude towards (1) Health and Hygiene, (2) Wild life, (3) Forests, (4) Polluters, (5) Population Explosion, (6) Environmental Concern. Each item alternative is assigned a weightage ranging from 4 (strongly agree) to 1 (strongly disagree) for favourable items. In case of unfavourable items the scoring is reversed, i.e., from 1 (Strongly agree) to 4 (strongly disagree). The attitude score of an individual is the sum total of item scores on all the six areas. The range of scores is from 61 to 244 with the higher score indicating the more favourable attitude towards environment and vice versa. Reliability of the scale as estimated by split half is 0.82 , which is highly significant.

The Taj Environmental Attitude Scale developed originally in English, was translated by the Investigator into Persian language for Iranian teachers and by the Indian translator into Kannada language, so three versions (English, Kannada and Persian) have been used in this study. Initially, the Kannada and Persian versions were administered as a pilot-test to 50 male teachers and 50 female teachers both in India and Iran to find out the suitability of the scale, with few minor revisions. The main study was continued based on the suggestions given by the teachers of pilot test. The split half reliability has been found to be .694 for Kannada version and 0.78 for Persian version.

Procedure: Both in India and Iran, the Investigator personally visited all the selected 
Table 1: Mean scores for various subscales of teachers environmental attitude with reference to countries and gender

\begin{tabular}{|c|c|c|c|c|c|c|c|}
\hline \multirow[t]{3}{*}{ Subscales } & \multirow[t]{3}{*}{ Gender } & \multicolumn{4}{|c|}{ Countries } & \multirow{2}{*}{\multicolumn{2}{|c|}{ Average }} \\
\hline & & \multicolumn{2}{|c|}{ India } & \multicolumn{2}{|c|}{ Iran } & & \\
\hline & & Mean & S.D & Mean & $S . D$ & Mean & $S . D$ \\
\hline \multirow[t]{3}{*}{ Health and Hygiene } & Male & 15.53 & 2.18 & 17.54 & 2.11 & 16.54 & 2.37 \\
\hline & Female & 15.81 & 2.42 & 17.96 & 2.03 & 16.88 & 2.48 \\
\hline & Total & 15.67 & 2.30 & 17.75 & 2.08 & 16.71 & 2.43 \\
\hline \multirow[t]{3}{*}{ Wild life } & Male & 16.63 & 2.75 & 17.25 & 3.19 & 16.94 & 3.00 \\
\hline & Female & 17.57 & 3.01 & 15.29 & 2.82 & 16.43 & 3.13 \\
\hline & Total & 17.10 & 2.92 & 16.28 & 3.17 & 16.69 & 3.07 \\
\hline \multirow[t]{3}{*}{ Forests } & Male & 15.28 & 2.22 & 15.80 & 2.41 & 15.54 & 2.33 \\
\hline & Female & 14.68 & 2.45 & 14.76 & 2.12 & 14.72 & 2.29 \\
\hline & Total & 14.98 & 2.36 & 15.28 & 2.32 & 15.13 & 2.34 \\
\hline \multirow[t]{3}{*}{ Polluters } & Male & 72.87 & 7.26 & 76.37 & 5.83 & 74.62 & 6.80 \\
\hline & Female & 73.05 & 8.94 & 78.04 & 6.49 & 75.54 & 8.20 \\
\hline & Total & 72.96 & 8.14 & 77.20 & 6.22 & 75.08 & 7.54 \\
\hline \multirow[t]{3}{*}{ Population Explosion } & Male & 16.04 & 2.58 & 16.65 & 2.32 & 16.35 & 2.47 \\
\hline & Female & 16.01 & 2.71 & 16.72 & 2.31 & 16.36 & 2.54 \\
\hline & Total & 16.03 & 2.64 & 16.68 & 2.31 & 16.35 & 2.50 \\
\hline \multirow[t]{3}{*}{ Environmental concern } & Male & 43.04 & 4.68 & 46.87 & 4.41 & 44.96 & 4.93 \\
\hline & Female & 44.51 & 4.85 & 46.98 & 4.63 & 45.74 & 4.90 \\
\hline & Total & 43.77 & 4.82 & 46.92 & 4.52 & 45.35 & 4.92 \\
\hline \multirow[t]{3}{*}{ Total } & Male & 179.39 & 13.27 & 190.46 & 11.65 & 184.95 & 13.65 \\
\hline & Female & 181.62 & 17.80 & 189.75 & 12.28 & 185.67 & 15.82 \\
\hline & Total & 180.51 & 15.72 & 190.11 & 11.96 & 185.31 & 14.76 \\
\hline
\end{tabular}

schools and teachers. Then teachers were met individually for explaining purpose of the study and were instructed how to respond to tool namely Environmental Attitude Scale as rated by teachers. Further clarifications were offered on the questions/doubts raised by them and they were requested to cooperate with the Investigator for successful completion of the research. Within the span of 6 months, the investigator could complete the data collection in both the countries.

Statistical Analysis: MANOVA (Multivariate Analysis of Variance) was employed to find out the significance of difference between countries in various subscales as well as the total attitude scores. Country and gender were considered for fixed factors in the analysis. Scores on various subscales as well as total attitude scores were considered as dependent variables together. SPSS for Windows (Evaluation Version 14.0) was used for the analysis.

\section{RESULTS}

Table 1 presents Mean environmental attitude scores on various subscales of male and female teachers working in India and Iran. Table 2 shows Results of MANOVA for Mean environmental attitude scores on various subscales of male and female teachers working in India and Iran.

\section{Main Effects}

a. Between Countries: In all the subscales including the total attitude scores MANOVA revealed significant differences between countries; In subscales like Health and Hygiene $(\mathrm{F}=-224.88 ; \mathrm{P}<.000)$, Forests $(\mathrm{F}=4.18 ; \mathrm{P}<.041)$, Polluters $(\mathrm{F}=86.36 ; \mathrm{P}<.000)$, population explosion $(\mathrm{F}=17.42 ; \mathrm{P}<.000)$, Environmental Concern $(\mathrm{F}=115.08 ; \mathrm{P}<.000)$ and lastly total attitude scores $(\mathrm{F}=118.32 ; \mathrm{P}<.000)$, teachers from Iran had significantly higher scores than their Indian counterparts, whereas only in one subscale i.e., Wildlife $(\mathrm{F}=19.68 ; \mathrm{P}<.000)$, Indian teachers had significantly higher scores than Iranian teachers.

b. Between Genders: Irrespective of the countries, male and female teachers differed significantly in most of the factors except in population explosion, and total attitude scores. Of the significant differences, male teachers had significantly higher scores in attitude towards Wildlife ( $\mathrm{F}=7.47 ; \mathrm{P}<.006)$, and Forests $(\mathrm{F}=31.69$; $\mathrm{P}<.000)$. Female teachers had higher scores in Health and Hygiene $(\mathrm{F}=6.53 ; \mathrm{P}<.011)$, Polluters $(\mathrm{F}=4.14 ; \mathrm{P}<.042)$ and environmental concern (7.30; $\mathrm{P}<.007)$. 
Table 2: Results of MANOVA for Mean scores for various subscales of teachers environmental attitude with reference to countries and gender.

\begin{tabular}{|c|c|c|c|c|c|c|}
\hline Source of variation & Dependent variable & Sum of Squares & $d f s$ & Mean square & $F$ & Sig. \\
\hline \multirow[t]{7}{*}{ Between countries (A) } & Health and Hygiene & 1079.19 & 1,996 & 1079.19 & 224.88 & .000 \\
\hline & Wild life & 171.32 & 1,996 & 171.32 & 19.68 & .000 \\
\hline & Forests & 22.18 & 1,996 & 22.18 & 4.18 & .041 \\
\hline & Polluters & 4508.51 & 1,996 & 4508.51 & 86.36 & .000 \\
\hline & Population Explosion & 107.67 & 1,996 & 107.67 & 17.42 & .000 \\
\hline & Environmental concern & 2481.27 & 1,996 & 2481.27 & 115.08 & .000 \\
\hline & Total attitude & 23044.90 & 1,996 & 23044.90 & 118.32 & .000 \\
\hline \multirow[t]{7}{*}{ Between gender (B) } & Health and Hygiene & 31.33 & 1,996 & 31.33 & 6.53 & .011 \\
\hline & Wild life & 64.98 & 1,996 & 64.98 & 7.47 & .006 \\
\hline & Forests & 168.00 & 1,996 & 168.00 & 31.69 & .000 \\
\hline & Polluters & 216.05 & 1,996 & 216.05 & 4.14 & .042 \\
\hline & Population Explosion & 0.08 & 1,996 & 0.08 & 0.01 & .912 \\
\hline & Environmental concern & 157.36 & 1,996 & 157.36 & 7.30 & .007 \\
\hline & Total attitude & 146.25 & 1,996 & 146.25 & 0.75 & .386 \\
\hline \multirow[t]{7}{*}{ Interaction $(\mathrm{AxB})$} & Health and Hygiene & 1.37 & 1,996 & 1.37 & 0.29 & .593 \\
\hline & Wild life & 525.49 & 1,996 & 525.49 & 60.37 & .000 \\
\hline & Forests & 12.08 & 1,996 & 12.08 & 2.28 & .132 \\
\hline & Polluters & 140.49 & 1,996 & 140.49 & 2.69 & .101 \\
\hline & Population Explosion & 0.71 & 1,996 & 0.71 & 0.12 & .734 \\
\hline & Environmental concern & 115.13 & 1,996 & 115.13 & 5.34 & .021 \\
\hline & Total attitude & 541.05 & 1,996 & 541.05 & 2.78 & .096 \\
\hline
\end{tabular}

Note: The significance levels in bold letters indicate significant values at .05 or .01 or .001 levels

c. Interaction Effects: Only two interaction effects were found to be significant of all the dependent variables considered between countries and gender. In the case of interaction effect between wildlife ( $\mathrm{F}=60.37 ; \mathrm{P}<.000)$, where in India females had higher attitude scores and in Iran male teachers had higher scores than their respective counterparts. In environmental concern $(\mathrm{F}=5.34 ; \mathrm{P}<.021)$ we did not find much difference between male and female teachers of Iran, however, in India, we find females had higher scores towards environmental concern than male teachers.

\section{DISCUSSION}

The main findings of the present study summarized as below:

In attitude towards health and hygiene, Iranian teachers had higher scores than Indian teachers as well as female teachers had higher scores than male teachers. In attitude towards wildlife, Indian teachers had higher scores than Iranian teachers as well as male teachers had higher scores than female teachers. In attitude towards forests, Iranian teachers had higher scores than Indian teachers as well as male teachers had higher scores than female teachers.

In attitude towards polluters, Iranian teachers had higher scores than Indian teachers as well as female teachers had higher scores than male teachers. In attitude towards population explosion, Iranian teachers had higher scores. In attitude towards environmental concern, Iranian teachers had higher scores than Indian teachers as well as female teachers had higher scores than male teachers. Overall, Iranian teachers had more positive attitude than Indian teachers towards environment.

It is quite clear that Iranian teachers have more positive environmental attitude than their Indian counterparts except in one subscale wildlife. Due to reasons such as the religiosity and values (also issues related to cow slaughter and many more which may not be an issue among Iranian teachers and moreover eating meat and food habits are culturally determined.) attached to wildlife and animals, the awareness may be high. For eg. the tiger being our national animal and lion is sacred and associated with goddess kali or the elephant to Lord Ganesh and so on. Hence, this reason could have influenced higher scores in attitude to wildlife among Indian teachers. Further, Article 48 A of Indian Constitution on Protection and improvement of environment and safeguarding of forests and wild life indicates that "The State shall Endeavour to protect and improve the environment and to safeguard the forests and wild life of the country". Even, NATIONAL POLICY ON 
EDUCATION (National Policy on Education 1986 as modified in 1992 with 1968.Govt of India Dept of Education, Ministry of Human Resource Development New Delhi 1998) regarding, Reorienting the content and process of education mentioned as "There is a paramount need to create a consciousness of the environment. It must permeate all ages and all sections of society, beginning with the child. Environmental consciousness should inform teaching in schools and colleges. This aspect will be integrated in the entire educational process. Therefore the National Policy on Education provides for the inclusion of environment as an integral part of the curriculum at all stages of education". However, in rest of the subscales Iranian teachers excelled Indian teachers. Moreover, there is a broad support across all types of nations for an International agency empowered to enforce environmental protection regulations, albeit somewhat less in the poorer countries. According to Dunlap (1994), residents of the wealthy nations tend to accept a good deal of responsibility for environmental problems, while those in poorer nations do not absolve themselves of blame. Similarly, when it comes to environmental problems within the less developed nations, there is a fairly similar tendency for both consumption among industrialized nations and overpopulation in developing nations to be seen as contributing factors.

Some of the findings obtained in the present study are partially in accordance with studies done earlier. Study by Sabhlok (1995) on teachers of Jabalpur district revealed that male and female teachers differed significantly on their environmental attitudes in favour of female teachers. Further a study on Rajastan teachers by Shahnawaj (1990) indicated the more that $95 \%$ of the teachers' possessed positive environmental attitude. Praharaj (1991) found among in service and pre-service secondary teachers, in-service group had a higher levels of attitude than the teachers of pre service group. But after several years the study being conducted, one can definitely say the amount of exposure by present day teachers generally lead to a favourable attitude towards environment and sustainable development.

The attitude of the teachers can be changed based on some of the strategies listed below

- Expose the teachers to recent developments in environmental issues like global warming and so on.
- Encourage teachers to participate in workshops and conferences where the threats to the globe are discussed

- Update the teachers' knowledge on environmental related issues by refresher courses/ crash courses.

- Compulsory environmental studies in all levels of education from primary to post graduation.

To conclude, a sustainable way of life calls for reorientation of a country's production system and consumption patterns, so that development can be economically efficient and ecologically sensitive. This calls for a radical change in the way we think, live and work. It therefore goes without saying that sustainable development calls for a paradigm shift in our educational system right from school level to university level. In fact, it cannot be thought of achieving a sustainable way of life without an appropriate educational system designed to internalize the principles of sustainability in the life and work of our youth. Because of the government initiative to make Environmental Education an integral part of formal education through its national curriculum framework, considerable work is being done in the direction of integrating environmental concepts into the existing curriculum, developing new strategies, preparing instructional material for effective implementation of Environmental Education in the formal system.

\section{REFERENCES}

Dunlap, R.E.: International attitudes towards environment and development. pp 115-126. In: Green Globe Year Book of International Co-operation on Environment and Development. Helge Ole Bergensen and George Parmann (Eds.). Oxford University Press, Oxford (1994).

Haseen Taj: Manual for Environmental Attitude Scale, Agra, India, Nandini Enterprises, (2001).

Jinarajan, S.A.K.: A Study of Environmental Awareness and Attitude Towards Environmental Education of Student Teachers of Bangalore City. M.Phil. dissertation (Unpublished), Bangalore University, Bangalore (1999).

Mercy, A. and Arjunan, N.K.: Environmental attitude and pro-environmental behaviour among secondary school children. EDUTRACKS,-A Monthly Scanner of Trends in Education, 4:32-34(2005).

Praharaj, B.: Environmental Knowledge, Environmental Attitude and Perception Regarding Environmental Education Among Pre-service and in Service Secondary School Teachers. Ph. D. Thesis (unpublished), The Maharaja Sayyaji Rao University of Baroda, Baroda (1991). 
Sabhlok, R.: A Study of the Awareness and Attitude of Teachers and Students of High Schools Toward Environmental Education in Jabalpur District. $\mathrm{Ph}$ D. Thesis (Unpublished), Ani Dugavati Vishwavidyalaya, Jabalpur(1995).

Shahnawaj, N.: Environmental Awareness and Environmental Attitude of Secondary and Higher Secondary School Teachers and Students. Ph. D. Thesis (unpublished). University of Rajasthan, Rajastan (1990).
Shaila, V. :Effect of Background Variables on the Environmental Attitude of Secondary School Teachers. M.Ed. Dissertation (Unpublished), Bangalore University, Bangalore (2003).

Yashodhara, K.: Role of NGOs in promoting non-formal environmental education-A case study in Bangalore district. SRTT Project Report Submitted to Institute for Social and Economic Change, Nagarabhavi, Bangalore 72 (2003). 